\title{
Comparative study in character education management models in Indonesia and India
}

\author{
Lia Yuliana * ${ }^{1}$, Sugiyono Sugiyono ${ }^{1}$, Suyanto Suyanto ${ }^{1}$, Kunal Mehta ${ }^{2}$ \\ ${ }^{1}$ Universitas Negeri Yogyakarta. \\ Jl. Colombo No. 1, Karang Malang, Depok, Sleman, Daerah Istimewa Yogyakarta 55281, Indonesia. \\ ${ }^{2}$ Lajpat Rai DAV Collage \\ Agwar, Gujjran, Jagraon, Punjab 142026, India. \\ lia_yuliana@uny.ac.id \\ * Corresponding Author
}

\section{ARTICLE INFO}

\section{Article History}

Received:

1 January 2021;

Revised:

1 January 2021;

Accepted:

2 January 2021

\section{Keywords}

Character education;

Comparability;

Model;

Management;

\begin{abstract}
The purpose of this research is to find out: 1.) Character education management models in Indonesia and India: Comparative study at Universitas Negeri Yogyakarta and Lajpat Raj DAV College Jagraon India; and 2.) Effectiveness of Character education management models in Indonesia and India: Comparative Study at Universitas Negeri Yogyakarta and Lajpat Raj DAV College Jagraon India. The method of this research was qualitative research and used a comparative study design approach. This research's most appropriate strategy was embedded research (stuck research) because the research has been planned in detail in the proposal before the researchers plunged into the field. The steps used were: 1.) Collecting source through multi-technique); 2) Reducing data to simplify and categorizing data; 3) Presenting data in the form of qualitative description; 4) Concluding; and 5.) Preparing research reports and formulating recommendations comparison research results. The research results show that the character education management model in Indonesia and India is almost the same. Whereas in Indonesia, it focuses more on religious and general characters, it is more on developing religious character in India. Meanwhile, the effectiveness of character education from Indonesia and India has been achieved by shaping students' character and other components, both for lecturers and education staff. Meanwhile, in India, public awareness and educators of the importance of education.
\end{abstract}

This is an open access article under the $\mathrm{CC}-\mathrm{BY}-\mathrm{SA}$ license.

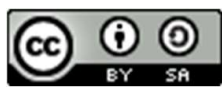

\section{INTRODUCTION}

Character education has become a central theme in the implementation of teaching at both elementary and college levels. Various education policy focuses on modeling the character education (Baehr, 2017; Bryan \& Babelay, 2009; Lickona, 1997; Nurdin, 2015; Arokiasamy, 2011; Sanderse, 2013). However, those policies' results are found contrast (Baehr, 2017; Bryan \& Babelay, 2009; Lickona, 1997; Nurdin, 2015; Arokiasamy, 2011; Sanderse, 2013; Tolbert, Mossberger, \& McNeal, 2008; Winton, 2008). The model of character building for children and adults is believed to be different. Hence, scholars explored and investigated the model of character education. The model of character education is found diverse. Theoretically, scholars argued that the model has to be integrated with the main objectives of the curriculum. Education is a strategic step to instill the ability and independence of life for humans. Education can shape human character to become wiser and 
wiser in living life. Education, both formal and non-formal, is the reason why humans can survive on earth. The existence of conflicts that often occur, especially in countries rich in culture, ethnicity, and religion, is commonplace due to shallow knowledge of differences and cultural wealth. Therefore, multicultural education is present in education to bridge the gap in knowledge of culture and languages. It is done to minimize the emergence of disputes between tribes and between individuals (Beachum, 2015; Anggraini, 2016). Multicultural education is important for building individual awareness of rapids (Bamford, Djebbour, \& Pollard, 2015). Individual care built from multicultural education is one of the education system's goals (Özturgut, 2011). Multicultural education objectives can be achieved if there is a synergy between schools, parents, students, and communities (Warshaw, Crume, \& Pinzon-Perez, 2020). Gao (2020) argued that schools should well plan multicultural education. According to Shapira, Kali, Kupermintz, and Dolev (2020), multicultural education planning is implemented by looking at schools' potential. According to Degand (2020), multicultural education in its application should pay attention to education level.

Today, character education is the main theme in the country's education administration, both from elementary school to vocational level. The Ministry of National Education has set the implementation of character education to begin in 2011. Educational institutions and all education levels carry out character education performance at the central and regional levels to become a national character education movement. The Ministry of National Education undertakes to be an example of providing services and implementing character education. This national character education movement has begun to be socialized in all educational institutions. Supporting tools for the implementation of character education has been prepared by the Research and Development Agency, the Ministry of National Education, which among others are in the form of "Character Education Master Design", training materials for strengthening learning methodology based on cultural values to shape the competitiveness and character of the nation as well as guidelines for implementing education character.

One of the national development program's priorities, as written in the Ministry of National Education's vision, is to realize a smart, comprehensive, competitive, and dignified Indonesian person through the implementation of character education. Intelligent comprehension includes spiritual, emotional, social, intellectual, and kinesthetic intelligence. The strategic plan was prepared based on Law Number 20 of 2003 concerning the National Education System. In Article 1 (one) of the law, it is written that education is a conscious and planned effort to create an atmosphere of learning and learning process so that students actively develop their potential to have religiousspiritual strength, self-control, personality, intelligence, morals, noble, as well as the skills needed by himself, society, nation, and state. After that, character education is also widely written in the vision and mission of other educational institutions. In general, academic institutions form a concept charged for making graduates smart and have good morals.

Character education has become one of the priorities of national development programs, as stated in the Ministry of National Education's vision, to realize Indonesian to be a comprehensive, competitive, and dignified human being. Intelligence comprehensiveness includes intelligent spiritual, emotional, social, intellectual, and kinesthetic. The strategic plan is based on Law number 20 of 2003 on National Education System. In article 1 (one) of the law, written that education is a conscious and planned effort to create a learning atmosphere and learning process, so that learners are actively developing their potential to have spiritual power, self-control, personality, intelligence, noble, as well as the skills he needs, society, nation, and state. Besides, character education is also widely written in the vision and mission of other educational institutions. In general, academic institutions form a vision that is charged to make graduates smart and noble.

Character education is the whole interrelated relational dynamic with various dimensions, both from within and outside. Thus, the person can increasingly live his freedom to be more responsible for the growth of himself as a person and others' development in their lives. Character education as pedagogy gives attention to three important things for human growth: the development of man's natural ability as it is owned differently by each individual (naturalist). In developing this natural ability, man cannot neglect his negative relation to the social Environment (Rosseau). In the relation between individual and society, a man directs himself to values (such as Foerster, Marx, Kohlberg, and Dithrey). Having a Noble Majesty is not automatically possessed by every human being once it 
is born. Still, it requires a long process through nurturing and education (the engraving process). In Arabic terms, the character is similar to akhlak (the root of khuluk), i.e., the character or habit of doing good. Ghazali (2010) illustrates that akhlak is the behavior of someone who comes from a good heart.

Character education is a shared responsibility for all educators, both at home and at school. Character education must begin with the educator itself. However, at this time, many negative characters are found that come from the educator itself. Although not based on accurate research data, but never found cases or events that tarnished educators' name. Educators who are studying advanced dishonestly in doing exam questions that copy their friend's answer. The educator helps the student to pass the national exam. Educators cheat in preparing promotional files and portfolio assessments, etc., which are assumptions that need to be verified. Suppose the educators only have shown a lot of negative characters keep doing. How will the students' character in the future? The phenomenon of the opposing characters of teenagers who often become a source of news in the mass media, among others, is the act of violence, brawl, mischief, cheating on the exam, and so forth. Elkins (2009) conducted a survey of bullying in schools, obtaining the following findings: Daily about 160,000 students were bullied in school, 1 out of 3 respondent age (students at 18 years of age) violent action, $75-80 \%$ of students have observed as violence, $15-35 \%$ of students are victims of violence cyber-bullying. It is undoubtedly a worrying picture for both the international community and Indonesia as well. Therefore, this phenomenon must be addressed seriously so that the red thread of the need for strengthening character education can be found, and the offered model solutions are also biased effectively and efficiently.

In its implementation, character education is strengthened through the 18 values that exist in the academic unit sourced from religion, Pancasila, culture, and the goals of national education, namely: religious, honest, tolerant, disciplined, hard work, creative, independent, democratic, curiosity, the spirit of nationalism, the love of the homeland, the appreciation of achievement, friendship/communicative, love of peace, love to read, caring environment, social care, and responsibility (Ministry of National Education of the Republic of Indonesia, 2010, p. 8). As a prospective educator, students should have a variety of good characters. One of them is creative, communicative, creative, and communicative must-have prospective educators in optimizing learning activities to achieve educational goals. As prospective educators, students are educated workers who can determine and influence dynamism in education. Quality students certainly have a sensitivity to the conditions that run in society. That sensitivity leads to curiosity into ideas that bring creativity. Creativity can give birth to a solution to solve various problems in the world of education. According to Hoesseini (2014), the invention can be developed in schools by teachers. In addition, according to Puspitasari, In'am, and Syaifuddin (2019), students play a role in creativity in the school. According to Vejian, Kamarudin, and Kadir (2016), the school must build a pleasant learning climate so that creativity arises.

This study focuses on studying the character education model held in Universitas Negeri Yogyakarta and Lajpat Rai DAV College Jagraon India. In many relationships, Indonesia and India have almost the same history and the same educational philosophy. If Indonesia has Ki Hajar Dewantara, then India has Mahatma Gandhi. Therefore, the study focused on the realities of implementing character education models at Universitas Negeri Yogyakarta and Lajpat Rai DAV College Jagraon India and the effectiveness of character education models at Universitas Negeri Yogyakarta Indonesia and Lajpat Rai DAV College Jagraon India. The results of this study will be an important input and character education program for Universitas Negeri Yogyakarta Indonesia and Lajpat Rai DAV College Jagraon India to develop a character education program dynamically and sustainably. Based on the background and the formulation problems, then formulated the research objectives as follows: 1.) Knowing the similarities and differences of Character education management models in Indonesia and India: Comparative Study at Universitas Negeri Yogyakarta and Lajpat Rai DAV College Jagraon India; and 2.) Knowing the achievement of Character education management models in Indonesia and India: Comparative study at Universitas Negeri Yogyakarta and Lajpat Rai DAV College Jagraon India.

Conceptually, management has definitions that are seen from various points of view. According to Sharma (2009, p. 66), Armstrong (2015), and Brown and Green (2006), management 
means getting people to do or what needs to be done. This conception is interpreted that management is an activity to guide people to work or do whatever is needed. The concept of management, according to Moorhead and Griffin (2014, p. 143), management is a process of planning, organizing, coordinating, and controlling any available resources to achieve the goals or goals that have been determined effectively and efficiently. To understand more about the functions of education management, in the perspective of schooling, by referring to Terry's (2012) thoughts, including 1.) Planning (planning); 2.) Organizing; 3.) Actuating; and 4.) Controlling. Planning is nothing but an activity to set goals to be achieved and ways to achieve those goals. As stated by Keith and Girling (1991) and Handoko (1995), planning may be defined as the process by which the manager sets objectives, assesses the future, and develops courses of action designed to accomplish these objectives.

Actuating activities carry out activities where managers try to influence so that they are motivated to complete their tasks. While controlling, monitoring activities are carried out so that Moorhead and Griffin (2014) can immediately correct them if there are irregularities. In the context of virtue, the character is a character, morality, or personality formed from the internalization of virtues that are believed and used as a basis for the worldview, thinking, attitude, and action. Integrity consists of values, morals, and norms, such as honesty, courage, trustworthiness, and respect for others. The interaction of someone with others fosters the character of society and the character of the nation. Therefore, the development of the character of the nation can only be done through the development of one's character. However, since humans live in specific social and cultural environments, the development of one's individual character can only be done within the social and cultural Environment (Puskur, 2010).

Research at Harvard University United States, Akbar (2009) and Ryan and Bohlin (1999) identifies a person's success is not determined solely by knowledge and technical skills (hard skills), but rather by the ability to manage themselves and others (soft skill). Meanwhile, according to Elkins (2009) and Lickona (2009), character education has the same essence and meaning as moral education and value education. The goal is to create a child's personality, be a good human being, a citizen, and a good citizen. Right human criteria, good citizens, and good citizens for a society or nation, in general, are specific social values, which are heavily influenced by the culture of society and government. Therefore, the essence of character education in Indonesia's context is the value of education, namely the noble values of education that comes from the Indonesian nation's culture itself, to foster the younger generation's personality.

In Indonesia, the Ministry of National Education (Kemendiknas) has formulated 18 values of character that will implant in the students to build the nation's essence (Suyadi, 2013). The MONE version of the character as stipulated in the book Development of Cultural Education and National Character of Ministry of National Education through the body of research and development of curriculum center (Ministry of National Education, 2010), as follows: 1.) Religious; 2.) Honest; 3.) Tolerance; 4.) Discipline; 5.) Hard Work; 6.) Creative; 7.) Independent; 8.) Democratic; 9.) Curiosity; 10.) Spirit of Nationality; 11.) Love Country; 12.) Respect for Achievement; 13.) Friendly/Communicative; 14) Love Peace; 15.) Love Reading; 16.) Care for the Environment; 17.) Social Care; and 18.) Responsibility. Similarly, Yogyakarta State University has become the driving force of the character education movement in Indonesia.

Indonesian national identity is a projection reflected in Indonesian people's behavior in general that is following the values contained in (Kartodirdjo, 2005). Action that follows the values in Pancasila is a true characteristic of the Indonesian nation in another concept, namely national identity. The word identity comes from the word identity (English), which has a literal understanding of the signs, characteristics, or identity attached to the individual or something that distinguishes it from the others. Identity in anthropology has a specific meaning that explains and follows one's selfawareness, group, group, community, or country.

\section{METHOD}

In this study, considering the type of research is an evaluation study, then the methodology used is also a way that strengthens the quality of qualitative research results. Various matters relating 
to the research methodology to be used in this study can be explained as follows. The method of this research was qualitative research and used a comparative study design approach. This research's most appropriate strategy was embedded research (stuck research) because the research has been planned in detail in the proposal before the researchers plunged into the field. The steps used were: 1.) Collecting source through multi-technique); 2.) Reducing data to simplify and categorizing data; 3) Presenting data in the form of qualitative description; 4.) Drawing conclusions; and 5.) Preparing research reports and formulating recommendations comparison research results.

\section{FINDINGS AND DISCCUSIONS}

\section{Character Education Management at Universitas Negeri Yogyakarta}

In character education management, Universitas Negeri Yogyakarta (UNY) refers to the vision and mission formulated in the strategic plan, both the old strategic plan and the new strategic plan. The vision of UNY to answer the challenges of education in the industrial era 4.0, which is used as a reference and direction for the development of UNY in carrying out its role in higher education, is: "To become a superior, creative, and innovative educational university based on piety, independence, and scholarship in 2025". The development of UNY towards a world-class educational university that is superior, creative, innovative, and sustainable, of course, does not override the basic values set by the founding fathers who have taken root in the UNY academic community, namely piety, independence, intellectuality, and Indonesian identity. Piety means that UNY always carries out activities on a blessed path by Allah SWT in carrying out his mandate. Independence refers to a strong self-ability in carrying out its mandate so that the dependent nature of thinking, acting, and acting is more likely to be initiated by oneself. Intelligence means that every thought, attitude, and action is always based on scientific truth, not individual or group interests.

Pancasila, the 1945 Constitution of the Republic of Indonesia, the Unitary State of the Republic of Indonesia, and Bhinneka Tunggal Ika, Indonesia's identity, must be upheld as a foundation in organizing UNY towards a world-class educational university that is superior, creative, innovative and sustainable. "Thus, morality, morality, self-efficacy, truth, and Indonesian identity are the essence of the basic values used by UNY in developing itself towards a world-class university." The values of Indonesian identity that underlie the development of UNY include the basic values of individuals and institutions. All of that is embodied in hope, as stated in the motto "Leading in Character Education," which is in line with the philosophy of education at UNY, namely the philosophy of Pancasila. UNY believes that education's primary purpose is to form character, namely individuals who can realize fundamental values in their lives. This motto is used as a UNY icon, included in various documents, and used in multiple activities at the local, national, regional, and international levels.

To develop UNY's strategic program in the future, it is necessary to adjust to the 2020-2024 UNY strategic plan by considering the RPJP, which will end in 2025. Thus, UNY's strategic plan for the 2020-2025 period needs to be a reference in the strategic development of UNY. The fourth (final) stage strategic plan in achieving UKKD refers to the corridors of higher education's main tasks and functions, namely: 1.) Human development according to natural abilities and in line with various needs; 2.) The development of science, technology, arts, and sports is beneficial for community development; and improving the lives of the Indonesian people and humanity through the dissemination of science, technology, arts, and sports. Therefore, the strategic efforts taken to realize UNY as UKKD are carried out based on a solid foundation, both legal, philosophical, and scientific (empirical) in line with the future demands of the Indonesian people as members of the world community, which are based on local excellence and national.

The implementation of strategic programs requires the full involvement of stakeholders both internally and externally. UNY internal stakeholders consisting of lecturers, academic staff, and students play an important role in successfully implementing the 2020-2025 UNY Strategic Plan. The existence of UNY's human resources as internal stakeholders is very important to carry out all of UNY's strategic plans and objectives. UNY's human resources' quality and quantity are also the basis for confidence in implementing programs to achieve strategic goals, program objectives, and 
targets set in the Renstra. UNY's human resources have many qualifications, potential, and contribution to education development at the national level. Many lecturers become assessors, reviewers, and consultants in the field of education at the national level. Thus, the national and international experience of UNY's human resources can be the basis for implementing the strategic plan.

UNY's internal human resources are empowered to become a major force in creating superior quality universities that can compete on a national and international scale. The toughest and most fundamental challenge for educational institutions is to create institutions that continue to learn together to provide added value to stakeholders. In realizing this goal, top management's commitment is required in laying the foundation for the transformation of the institution's work culture in total. Work culture is meant to be a value system, a collective agreement of all those involved in the institution. The implementation of the 2020-2025 UNY Strategic Plan also involves UNY's external stakeholders. External stakeholders, including domestic and foreign partner institutions, practitioners of the business world and the industrial world, local governments, and other users of UNY graduates, have contributed to the successful implementation of the 2020-2025 UNY strategic plan. UNY leadership must optimize internal and external stakeholders' support in a synergic and sustainable manner based on local and national excellence to compete in the international arena.

At UNY, the implementation of character education is inseparable from the well-organized practice of character education management. The direction of our character education today is to rediscover the national identity, restore the national identity, and rebuild the national identity that was lost amidst the nation's journey in this globalization era, to increase the competitiveness of this nation's human resources during the era of globalization and the market. Law No. 20 of 2003 on the National Education System in article 3 states that national education has the function of developing capabilities and shaping dignified national character and civilization to educate the nation's life. National education aims to develop students' potential to become human beings who believe and obey God Almighty, have a noble character, are healthy, knowledgeable, capable, creative, independent, and become democratic and responsible citizens. Based on national education's functions and objectives, it is clear that education at every level must be organized systematically to achieve these goals. This is related to students' character-building to compete ethically, morally, and politely in interacting with society. The characters referred to are the values of human behavior related to God Almighty, self, fellow human beings, the environment, and nationality, manifested in thoughts, attitudes, feelings, words, and actions based on religious norms, law, order, manners, culture, and customs. Character education instills character values to school members, including knowledge, awareness or willingness, and tin.

The second is Organizing, organizing resources, human resources, material resources, or supporting resources as executors of the character education strengthening program at UNY. At the rectorate level, UNY leaders, deans, department heads, lecturers, and education staff are synergistically organized to mutually support the achievement of character education strengthening programs. Synergy is built at the university level through various programs integrated with Tri Dharma activities, namely education, research, and community service activities. To support the implementation of character education strengthening program activities, coordination is an effective means that between leaders at the university level, faculty or departmental institutions synergically supports each other. In a broader context, campus student organizations' involvement can accelerate implementing the character education strengthening program at UNY. Additional resources, such as funding, are support resources that also can affect the character education strengthening program's success. Organizing these resources as a model of organizing management practices greatly influences the program's success.

Third, actuating, namely the implementation of the character education strengthening program, is an illustration both in the grand design context and at the class level, namely the implementation of character education at the class level by applying RPS compiled by lecturers. In the implementation of character education at the faculty, there are several variants, of some specifically organize courses with the name character education courses. Still, some are integrated with both productive and non-productive courses. The implementation of character education aims to make students, lecturers, education staff, and the community into character. It may be that the 
implementation of character education starts from coercion compulsion, but in the end, it becomes accustomed, becomes the character and personality of the academic community. In the research field, character education is determining research schemes and PPM that have character. This aims to realize the character education strengthening program among students, lecturers, academic staff, and the community.

Fourth, controlling is an activity to ensure the implementation of the character education strengthening program at UNY. This activity is carried out in good management practice by the chancellor, dean, and department head. The institution that carries explicitly out monitoring and evaluation, as well as an audit system, is the Quality Assurance and Education Development Institute (LPMPP). This institution controls how the character education program is implemented down to the class and subject levels, both at the beginning of the semester, mid-semester and at the end of the semester. Hail monitoring and evaluation is material for reflection and follow-up for the next improvement and revamping of the program. Based on the research results through interviews, questionnaires, and observations, the implementation of character education at UNY has been effective, as evidenced by students, lecturers, and educational staff's increasingly characteristic characteristics. Among students, the higher the level of education, the more character the student will be. Strata-3 is more characteristic than Strata-2, and Strata-2 is more characteristic than Strata-1. This shows that the higher a person's education level, the more character the human being is concerned.

\section{Character Education Management at Lajpat Rai DAV College Jagraon India}

The college encourages the students to earn while learn scheme. In this scheme, needy students are offered various data entry jobs in the administrative office and library. The students are paid accordingly so that they can manage their expenses along with the studies. Such activities enable students to properly handle a variety of office jobs. Hawan Yajna is performed every month. The principal of the college delivers a lecture on moral values after the Hawan Yajna. Through this activity, the students are morally motivated to lead to a higher life. The college is managing organic waste to generate manure in the college ground. This is an environmentally friendly activity of the college. Through this waste management, we generate manure, which is an organic fertilizer. Even the students of our college get the awareness of manure's generation and its benefits over chemical fertilizers.

India chose a commitment to disseminate knowledge and freedom of thought among the population, which is reflected in the policy in its law, namely article 45 states that the State seeks to provide free education for ten years and children until they are 14 years old. Meanwhile, Article 29, paragraph 1 , states that citizens who have various languages and writings receive special treatment in the economic sector. Since 1976, the Central Government has decided to be responsible for financing and regulating primary to secondary education and coordinating with higher education programs. The Government also provides equal opportunities in general education.

This education system was influenced by Mahatma Gandhi, who had the idea of forming a "complete, creative and productive personality." The department that deals with education issues is the Ministry of Education and Welfare. The Government decides that education policy is adopted based on the federal parliament's provisions, while the Government only acts as the implementer. This idea came about based on a suggestion from the Human Resources Development Department. In 1990, India formed a small modification committee that worked for two years to revise its longterm education program.

Since 1976, the central Government has assumed responsibility for financing and setting upper to secondary education standards and coordination with higher education programs. The quality of education in India that can compete in the international world does not appear suddenly. Several factors drive the progress and development of education in India, including First, modern universities in India have been established since 1857 and are well established. Some of the most famous campuses in India have been around since the British colonial period. With this long age, they have enough experience and maturity in the management system and efforts to improve India's quality of human resources.

Second, English is the language of instruction in India's educational institutions and government agencies. By using English, students in India no longer have problems gaining various

Volume 7, No. 2, September 2020 
knowledge from all perspectives and approaches with many references. Third, Indian lecturers at least have completed doctoral education (S-3). Not a few of them have achieved S-2 and S-3 several times. Therefore, it is not uncommon for us to find lecturers with multiple degrees, such as Dr. Gurusami, M., Sc., M.E.D., Ph.D. Fourth, India develops various campuses that focus on one particular field of science, which then becomes a pillar of strength for education in India, where quality alumni are undoubtedly in the international world.

Observing Lajpat Rai DAV College Jagraon India's vision and mission, character development is full of religious and human values. According to the vision and mission, the curriculum is structured, prioritizing a religious campus's character and can have competitive competencies towards developing science and technology. Character education programs are well system, starting from planning, organizing, implementing, and monitoring. The management of character education that is implemented is that all persons have character according to the vision and mission both at the rectorate level and at the faculty and department levels. The controlling agency is the leader in each unit. Lecturers have an important role in implementing character education at the class level, from designing, organizing, implementing, to supervision. In this context, the character is formed first, starting from the religious background, then becoming the basis for character education development on campus. Students feel disciplined towards lecture activities, take assignments seriously, and uphold togetherness.

Therefore, both Universitas Negeri Yogyakarta and Lajpat Rai DAV College Jagraon India's management practices have similarities, starting from the formulation of the vision and mission to implementing programs that refer to the vision and mission. In implementing the character education program at Lajpat Rai DAV College in Jagraon, India, there is a harmonization between university leaders, deans, heads of departments, lecturers, education staff, and students. Students are not only as objects of enhancing character education but also as subjects who have a role in implementing character education that creates a religious campus situation. A religious campus atmosphere has a balanced impact on attitudes and skills. So the aspects of attitude and skills, as well as balanced knowledge, build an identity in the form of character and personality. However, there are cultural differences between Indonesia and India, but it is related to a culture owned by the owner of that culture. According to India, it is very civilized, but according to Indonesia, it is uncivilized, and or vice versa. In general, the management of character education at LR DAV College Jagraon India has been proven by students' excellent character, tolerance, and respect for one another even though they are of different ethnicities and religions.

\section{Comparison of character education models in Indonesia and India}

Based on the research results and identification of the character education management model at UNY and at LR DAV College Jagraon India, a comparison can be formulated as shown in Table 1. Comparatively, the character education management model at Universitas Negeri Yogyakarta and Lajpat Rai DAV College University is the same. The management model departs from the formulation of a vision and mission that has led to efforts to cultivate character education in all campuses, including lecturers, education staff, and students. Campus locality is very influential. The problem of character education is not new for the Indonesians and Indians, even though it used to be mostly carried out informally and non-formally. Education is mainly carried out by parents and community leaders as well as by lecturers in an integrated manner with lectures that what it teaches. Since ancient times our nation has been known to have good character, honesty, discipline, respect for others, likes to help, works together, wants to sacrifice, and other positive characters. However, lately, our nation seems to have lost such character. In terms of politeness, sometimes we can even say that it is more impolite than even a country known to be liberal. Those nations that are known to be liberal if they want to criticize or reject others' opinions still have "excuse me" pleasantries and are expressed politely. However, we rarely pay attention to such norms. If we disagree or do not agree with other people's opinions, it is not uncommon for us to attack rudely, sarcasm, or even physical confrontation.

We have rarely encountered such things in western countries or other developed countries, known as individualists and liberals. Strange indeed, but that is a reality that we face today. History 
has recorded that the education of a nation without good character education will not lead to optimal success. Positive characters such as obedience to God Almighty, honesty, discipline, responsibility, respect for others, helping others, willingness to sacrifice, being able to cooperate with others, and other positive characters are needed to optimize the achievement of national education goals and in the framework of human resource development in this beloved country. Maybe without good character education, we can succeed in achieving exemplary academic achievements, but it is possible that such good academic achievements will not bring any benefits to national development. In fact, it will be a disaster for the nation. Many cases of corruption, or abuse of authority, are carried out by people who have high academic achievements but do not have positive characters.

Table 1. The Result of Comparison The Character Education Models

\begin{tabular}{|c|c|c|}
\hline Aspects & Universitas Negeri Yogyakarta & Lajpat Rai DAV College \\
\hline Vision & $\begin{array}{l}\text { To be a superior, creative and } \\
\text { innovative educational } \\
\text { university based on fear, } \\
\text { independence, and self-reliance } \\
\text { by } 2025\end{array}$ & $\begin{array}{l}\text { Providing our students with value } \\
\text { based education while equipping } \\
\text { them with necessary skills required } \\
\text { to face and overcome the challenges } \\
\text { of ever changing, competitive and } \\
\text { global world }\end{array}$ \\
\hline Mission & $\begin{array}{l}\text { There are } 7 \text { Mission } \\
\text { Formulations with indicators } \\
\text { academic education, profession } \\
\text { and vocational, Research, PPM, } \\
\text { governance, environment, } \\
\text { cooperation }\end{array}$ & $\begin{array}{l}\text { There are } 4 \text { indicators of } \\
\text { achievement, namely providing } \\
\text { intellectual, social, moral and } \\
\text { spiritual oriented citizens for the } \\
\text { nation. }\end{array}$ \\
\hline $\begin{array}{l}\text { Character Education } \\
\text { Foundation }\end{array}$ & (5 Sila) Pancasila & (10 Principles) Arya Samaj \\
\hline Character Education & Integrated in Academic and Non & Holistic in Academic and Non \\
\hline Model & Academic Programs & Academic Aspects \\
\hline $\begin{array}{l}\text { Education } \\
\text { Management Model }\end{array}$ & $\begin{array}{l}\text { Model Planning, Organizing, } \\
\text { Actuating and Controling (P-O- } \\
\text { A-C) }\end{array}$ & $\begin{array}{l}\text { Model Planning, Implementation } \\
\text { and Evaluation (P-I-E) }\end{array}$ \\
\hline $\begin{array}{l}\text { Human Resources } \\
\text { Involvement }\end{array}$ & All Stakeholders & All Stakeholders \\
\hline At Class Level & $\begin{array}{l}\text { Integrated and Stand-Alone } \\
\text { Courses }\end{array}$ & Integrated with Courses \\
\hline At reachability Level & $\begin{array}{l}\text { Achieved well in all programs } \\
\text { both academic and non- } \\
\text { academic }\end{array}$ & Achieved Holistically in all aspects \\
\hline
\end{tabular}

They turned out to have excellent abilities academically, but unfortunately, they were not matched by good character. Unfortunately, those who should be able to play an active role in the development of this nation become a disaster for our country. So far, character education in schools is burdened only on religious teachers. In reality, it cannot achieve optimal learning outcomes because the character education carried out cannot be contextual. Character education must be contextual in the sense that it is attached to certain subjects/subjects' case and context. Thus character education should be attached to the subject/course or field of study being taught. For example, when a teacher/lecturer teaches computer science, the teacher must simultaneously instill character education. The inherent character education, for example, the teacher explains that a computer is a 
sophisticated tool, but its use depends on the people behind it. It is carried out in various learning strategies to optimize the achievement of "nurturent effect" or optimal accompaniment goals.

The results of research at Havard University in the United States show that a person's success is determined by technical knowledge and abilities (hard skills) and the ability to manage oneself and others (soft skills). This research reveals that success is only determined by around 20 percent by hard skills and the remaining 80 percent by soft skills. Even the most successful people in the world can succeed because they are supported more by soft skills than hard skills. This suggests that the quality of character education is very highly important to improve. Soft skills are part of the character formed through education from early childhood to tertiary education. The Ministry of National Education has developed a character education grand design for each track, level, and educational unit type. This grand design is a conceptual and operational reference for development, implementation, and assessment at every pathway and level of education.

Based on the Grand design of national character education, it is stated that the character configuration in the context of the totality of the psychological and sociocultural processes is grouped into spiritual and emotional development, intellectual development, sports and kinesthetic (Physical and kinesthetic development), and sports. Taste and Creativity development. A person's character that is formed will be influenced by the mindset and attitude pattern adopted by a person/student. Suppose the pattern of thought and attitude adopted is based on faith and piety towards God as the creator and regulator of his creatures. In that case, it will form the right and strong character that is implemented in everyday life in society, be it the character towards oneself, others, the environment, and the nationality which is obtained through activities of thought, the exercise of the heart, sports, and exercise of feeling and initiative. Character education should give meaning to life and is upheld, which colors and animates one's actions. This definition explains that value.

The implementation of character education inherent in subjects/courses cannot be separated from schools/campuses' participation and support of schools/campuses. Schools/campuses should provide support through acculturation in all activities and school/campus atmosphere. Culture will create a habit. To foster a positive character, schools/campuses need to plan culture and habituation activities. Habit is a good educational tool in character education. For students (especially those who are still young), habituation is very important because it is with habituation that eventually an activity will belong to students later. Good habits will form a human figure with a good personality too.

Conversely, bad habituation will form a human figure with a bad personality as well. This habituation can be done by giving assignments or applying activities through specific learning methods, such as group work and discipline assignments. It can also be done through prayer together at the beginning and at the end of learning under the teacher's guidance. It is believed that the development of character education is necessary and important to be carried out by schools and their stakeholders to become a foothold in implementing character education in schools.

Character education is developed through the knowing, acting, and habit stages. Character is not limited to knowledge alone. A person who has good knowledge cannot act according to his knowledge if he is not trained (becomes a habit) to do that right. The character also reaches into the emotional and habitual realm of oneself. Thus, three components of good character are needed, namely moral knowing (knowledge of morals), moral feeling (emotional reinforcement) about morals, and moral action or moral actions. This is necessary so that students and other school members involved in the education system can understand, feel, live, and practice (work on) virtue (moral) values.

The dimensions included in moral knowing that will fill the cognitive realm are moral awareness, knowing moral values, perspective-taking, moral reasoning, courage to take a stand. (decision making), and self-introduction (self-knowledge). The moral feeling is the strengthening of the emotional aspects of students to become human characters. This strengthening is related to the forms of attitudes that students must feel: conscience, self-esteem, self-esteem, and sensitivity to people's suffering (empathy), love of truth (loving the good), self-control (self-control), and humility (humility). Moral action is an act or moral action, which is the other two-character components' result (outcome). To understand what drives someone to act morally, we must look at three different aspects of character: competence, will, and habit (Masyhud, 2012a). Character development in an educational system is the relationship between character components that contain behavioral values, 
which can be done or acted gradually and are interconnected between knowledge of behavioral values with strong attitudes or emotions to implement them, both towards God Almighty, himself, neighbor, environment, nation, and the state as well as the international world.

Character education should lead students to cognitive value recognition, affective appreciation of values, and finally, to real value practice. Character education must be implemented up to higher education. However, the implementation of character education in schools and higher education should not be too burdensome for students. Character education does not need to be carried out in the form of separate courses but must be integrated into various existing courses to be contextual. Thus character education will be more meaningful for students. Character education must be emphasized on direct and more effective methods, highlighting forms of practice and selfreflection rather than theory, so that learning outcomes can be achieved more effectively.

Character education is very complicated. To be able to properly carry out character education and the results to be effective, character education must be supported by various sources. Character education is not sufficiently carried out with mere theories, but what is more important are deeds, examples, and attitudes. Character education must be based on local wisdom and context. Therefore, various sources of character "values" from society must be used as material for character education. The development of character education at Universitas Negeri Yogyakarta and at Lajpat Raj DAV College University is based on management practices. This is where the role of education management is needed. Educational management that is suitable for this is the management of education management must be able to synchronize the character education program carried out by the school with the family and community around it. Character education programs in schools must be designed jointly between schools, parents, and the community. In implementation and supervision, there must also be togetherness between the campus, family, and community.

\section{CONCLUSION}

The research results indicate that the character education management model in Indonesia and India is almost the same. Suppose in Indonesia. It focuses more on religious and general characters in India. In that case, it is more on the development of religious morality. Meanwhile, the effectiveness of character education from Indonesia and India has shaped students and other components, both lecturers and academic staff. Education problems in almost all developing countries are generally the same, ranging from school fees, illiteracy, dropping out of school, and the curriculum to the education budget. However, everything can change as long as the government and all related elements are strongly committed to advancing education in their respective countries. The quality of the education system significantly influences the development of a society and nation because it brings significant changes to its life. The successes achieved basically cannot be separated from the support of existing government policies. Meanwhile, in India, the public and educators' awareness of education's importance has made India one of the countries whose education is quite taken into account in the international world.

One aspect that supports education in India is providing textbooks for schools and universities that are cheap. Besides cheap books, education in India is also affordable. Free education to Higher Education. Another supporter is the application of English as the language of instruction in almost all universities in India. At primary, secondary, and tertiary levels, education in India emphasizes simplicity. The educational building is physically apprehensive, but higher education in India is relatively prominent in terms of quality. Character education in schools has a strategic value in improving the quality of teaching and developing human resources in the era of globalization. Therefore character education in schools must be handled remarkably by using various methods between theory and practice. Good character education must be carried out synergistically between higher education institutions, parents, and the community. Each party should complement and control the implementation of character education that is carried out. Higher education instills character education in students, parents, and the community to assist in its execution, supervision, and university input. For character education to be carried out optimally, it must be supported by effective education management. Management education in character education is needed in planning, implementation, control, and assessment. 


\section{REFERENCES}

Akbar, A. I. (2009). Praktik pendidikan di Indonesia. Jakarta: Puspa Warna.

Arokiasamy, A. R. A. (2011). An Analysis of globalization and higher education in Malaysia. Online Submission.

Badan Penelitian dan Pengembangan Kementerian Pendidikan Nasional Republik Indonesia. (2010). Pengembangan pendidikan budaya dan karakter bangsa. Kementerian Pendidikan Nasional Republik Indonesia. Retrieved from http://newindonesia.org/beranda/images/upload/dok/kurikulum/pengembangan-pendidikan-budayadan-karakter-bangsa.pdf

Baehr, J. (2017). The varieties of character and some implications for character education. Journal of youth and adolescence, 46(6), 1153-1161. doi: https://doi.org/10.1007/s10964-017-0654$\underline{\mathrm{Z}}$

Bamford, J., Djebbour, Y., \& Pollard, L. (2015). I'll do this no matter if I have to fight the world!. Journal for Multicultural Education, 9(3), 140-158. doi: http://doi.org/10.1108/JME-05$\underline{2015-0013}$

Brown, A., \& Green, T. D. (2006). The essentials of instructional design 'connecting fundamental principles with process and practice. New Jersey: Pearson Prentice Hall.

Bryan, C. S., \& Babelay, A. M. (2009). Building character: A model for reflective practice. Academic Medicine, 84(9), 1283-1288. doi: https://doi.org/10.1097/ACM.0b013e3181b6a79c

Degand, D. (2020). Introducing critical race media literacy in an undergraduate education course about technology and arts-based inquiry. International Journal of Multikultural Education, 22(3), 96-117. doi: http://dx.doi.org/10.18251/ijme.v22i3.2461.

Elkins, D. N. (2009). Why humanistic psychology lost its power and influence in American psychology: Implications for advancing humanistic psychology. Journal of Humanistic Psychology, 49(3), 267-291. doi: https://doi.org/10.1177/0022167808323575

Gao, J. (2020). Asian American student's perceptions of social studies. International Journal of Multikultural Education, 22(3), 76-95. doi: http://dx.doi.org/10.18251/ijme.v22i3.2515

Ghazali, A. (2010). Paduan akhlak dan hati. Jakarta: Ghalia.

Handoko, T. H. (1995). Manajemen (2nd ed). Yogyakarta: BPFE UGM.

Hosseini, A. S. (2014). The effect of creativity model for creativity development in teachers. International Journal of Information and Education Technology, 4(2), 138-142. doi: https://doi.org/10.7763/IJIET.2014.V4.385

Kartodirdjo, S. (2005). Sejak Indische sampai Indonesia. Penerbit Buku Kompas.

Keith, S., \& Girling, R. H. (1991). Education, management, and participation: New directions in educational administration. Allyn \& Bacon.

Kementerian Pendidikan Nasional Republik Indonesia. (2010). Grand design pendidikan karakter. Jakarta: Kemendiknas.

Lickona, T. (2009). Educating for character: How our schools can teach respect and responsibility. Bantam.

Lickona, T. (1997). The teacher's role in character education. Journal of education, 179(2), 63-80. doi: https://doi.org/10.1177/002205749717900206

Moorhead, G., \& Griffin, R. W. (2008). Organizational behavior managing people and organizations. Dreamtech Press. 
182 - Harmoni Sosial: Jurnal Pendidikan IPS

Nurdin, E. S. (2015). The policies on civic education in developing national character in Indonesia. International Education Studies, 8(8), 199-209. doi: https://doi.org/10.5539/ies.v8n8p199

Özturgut, O. (2011). Understanding multikultural education. Current Issues in Education, 14(2), 111. Retrieved from http://cie.asu.edu/ojs/index.php/cieatasu/article/download/732/225

Puspitasari, L., In'am, A., \& Syaifuddin, M. (2018). Analysis of students' creative thinking in solving arithmetic problems. International Electronic Journal of Mathematics Education, 14(1), 4960. doi: https://doi.org/10.12973/iejme/3962

Presiden Republik Indonesia. (2003). Undang-Undang Republik Indnesia Nomor 20 Tahun 2003 tentang Sistem Pendidikan Nasional.

Ryan, K., \& Bohlin, K. E. (1999). Building character in schools: Practical ways to bring moral instruction to life. San Fransisco: Jossey-Bass Inc.

Sanderse, W. (2013). The meaning of role modelling in moral and character education. Journal of Moral Education, 42(1), 28-42. doi: https://doi.org/10.1080/03057240.2012.690727

Shapira, N., Kali, Y., Kupermintz, H., \& Dolev, N. (2020). Teachers foster intergroup empathy. International Journal of Multicultural Education, 22(3), 1-23. doi: http://dx.doi.org/10.18251/ijme.v22i3.2225

Sharma, S. L. (2009). Educational management: A unified approach of education. Global India Publications.

Terry, G. R. (2012). Principles of management: Irwin series in industrial engineering and management. Montana: Literary Licensing, LLC.

Tolbert, C. J., Mossberger, K., \& McNeal, R. (2008). Institutions, policy innovation, and EGovernment in the American States. Public Administration Review, 68(3), 549-563. doi: https://doi.org/10.1111/j.1540-6210.2008.00890.x

Vejian, G., Kamarudin, N., \& Kadir, S. A. (2016). School creative climate: Factors influence fostering creativity school. International Journal of Education and Training, 2(1), 1-5. Retrieved from http://www.injet.upm.edu.my/images/journal/isujun2016/School\%20Creative\%20Climate \%20Factors \%20Influence $\% 20$ Fostering\%20Creativity $\% 20 \mathrm{in} \% 20$ School.pdf

Warshaw, J. S., Crume, P., \& Pinzon-Perez, H. (2020). Impact of service-learning on hispanic college students: Building multi-cultural competence. International Journal of Multicultural Education, 22(3), 50-75. doi: http://dx.doi.org/10.18251/ijme.v22i3.2413

Winton, S. (2008). The appeal (s) of character education in threatening times: Caring and critical democratic responses. Comparative Education, 44(3), 305-316. doi: https://doi.org/10.1080/03050060802264843 